\title{
Aplikasi Mini Payroll Pada CV. Citra Karya Mandiri Bekasi
}

\author{
Rahayu Ningsih ${ }^{1}$, Verra Sofica ${ }^{2}$, Minda Septiani ${ }^{3}$, Andro Dewa Pratomo ${ }^{4}$, \\ Moch. Zely Eko Feriyanto 5 , Eko Haryanto ${ }^{6}$ \\ 1,3,4,5,6 Universitas Bina Sarana Informatika \\ Email: ${ }^{1}$ rahayu.ryh@bsi.ac.id, ${ }^{3}$ minda.mdt@bsi.ac.id, ${ }^{4}$ androdewap@gmail.com, \\ 5aranuri36@gmail.com, ${ }^{6}$ echoharyanto@gmail.com \\ ${ }^{2}$ Universitas Nusa Mandiri \\ Email: verra.vsc@nusamandiri.ac.id

\begin{tabular}{ccc}
\hline Diterima & Direvisi & Disetujui \\
$01-11-2021$ & $14-11-2021$ & $29-11-2021$ \\
\hline
\end{tabular}

\begin{abstract}
Abstrak - Sesuai Dengan Catatan pada Situs Medcom.id Pelaku bisnis yang baru merintis usaha biasanya belum memikirkan sistem pengelolaan sumber daya manusia (SDM) secara otomatis. Pada saat ini CV. Cipta Karya Mandiri hanya berupa perusahaan yang bergerak dalam bidang Kontruksi Besi. Sistem yang ada pada perusahaan ini masih dilakukan secara manual, mulai dari pencatatan absensi pada karyawan, sampai penggajian serta data-data lainnya yang berhubungan dengan masukan data hingga sampai pembuatan laporan, kemungkinan terjadinya kesalahan pada proses pencatatan dan pemrosesan data menjadi sangat besar, laporan menjadi tidak akurat dan membutuhkan waktu yang lama saat pencarian. Untuk menyelesaikan masalah tersebut peneliti menggunakan metode pengembangan perangkat lunak yaitu waterfall dan membuat sebuah aplikasi berupa web payroll sederhana menggunakan Codeiqniter, MySql, dan Bootstrap. Sehingga proses penghitungan gaji yang rumit sudah lebih efisien dan praktis karena sudah otomatis terhitung sistem, pengarsipan data pengeluaran gaji di menjadi lebih rapih dan aman karena data tersimpan di sistem dan kekeliruan antara waktu kerja dengan penghitungan gaji karyawan terminimalisir.
\end{abstract}

KataKunci : penggajian, waterfall, CodeIgniter

\begin{abstract}
In accordance with the notes on the Medcom.id site, business people who are just starting a business usually have not thought about an automatic human resource management (HR) system. At this time CV. Cipta Karya Mandiri is only a company engaged in the Iron Construction sector. The existing system at this company is still done manually, starting from recording employee attendance, to payroll and other data related to data input to making reports, the possibility of errors in the recording and data processing process becomes very large, reports become inaccurate and takes a long time to search. To solve this problem, the researcher uses a software development method, namely the waterfall and creates an application in the form of a simple payroll web using Codeiqniter, MySql, and Bootstrap. So that the complex salary calculation process is more efficient and practical because the system is automatically calculated, the archiving of salary expenditure data becomes neater and safer because the data is stored in the system and errors between working time and calculating employee salaries are minimized.
\end{abstract}

Keywords : sallary, waterfall, CodeIgniter

\section{PENDAHULUAN}

Sesuai Dengan Catatan pada Situs Medcom.id Pelaku bisnis yang baru merintis usaha biasanya belum memikirkan sistem pengelolaan sumber daya manusia (SDM) secara otomatis. Padahal dengan pengelolaan SDM yang baik, bisnis sekecil apapun bisa mendapat peluang apik. Hal ini pasti akan berpengaruh pada perhitungan gaji setiap bulannya. Pengelolaan di ruang lingkup HR ini menjadi masalah klasik bisnis kecil di Indonesia, kata Chief Commercial Officer PT Mid Solusi Nusantara (Mekari) Sandy Suryanto. (Ade Hapsari Lestarin, 2020;)
Penelitian oleh Supri Andoko (Andoko, 2013), di CV. Mobile Cell Pacitan. Bahwa membahas penggajian merupakan masalah yang sangat sensitif, terjadi sedikit saja ada ketidaksamaan akan menyebabkan suatu perusahaan atau instansi mengalami kerugian. Dan berdasarkan penelitian yang dilakukan oleh Triaswati Yuni Wulandari (Jurnal et al., 2012) dalam laporannya yang berjudul "Sistem Komputerisasi Penggajian Guru Pada Sekolah Menengah Pertama 2 Sambungmacan". Teknologi ini mempunyai peranan sebagai keunggulan teknologi pada saat ini, terlebih perkembangan teknologi dibidang komputerisasi 
sangat dibutuhkan dalam membantu semua kegiatan dan pekerjaan manusia.

Penelitian yang dilakukan oleh peneliti pada CV. Citra Karya Mandiri Bekasi masih memproses penggajian secara manual, sehingga dalam proses pengolahan penggajian menjadi kurang kurat, waktu yang lebih lama, dan pencarian data yang lebih sulit. serta tidak terorganisir dengan baik. Pada proses perhitungan gaji masih terkesan manual (Hidayatun, 2016). Pembuatan laporan yang masih dicatat menggunakan tangan ke dalam kertas atau buku (Muhammad et al., 2016). Perhitungan gaji yang salah dapat menyebabkan mundurnya waktu pemberian gaji pada karyawan (Entas \& Alawiah, 2015). Melihat dari trend sekarang dan penelitian sebelumnya penulis ingin mengimplementasikan sebuah aplikasi Mini Payroll kedalam tempat riset kami di CV. Cipta Karya Mandiri yang bergerak di bidang usaha kontruksi besi, berupa aplikasi web payroll sederhana menggunakan Codeiqniter, MySql, dan Bootstrap. Tujuan penelitian ini adalah untuk mengetahui bagaimana merancang dan menerapkan system penerimaan gaji yang terkomputerisasi sebagai salah satu solusi terhadap masalah yang dihadapi perusahaan serta membantu meningkatkan efisiensi sehingga proses perekapan dan pembbuatan laporan menjadi lebih efektif.

\section{METODE PENELITIAN}

\section{A. Metode Pengembangan Perangkat Lunak}

Dalam pengembangan sistem informasi ini peneliti menggunakan model SDLC (Software Development Life Cycle) air terjun. Tahapan pada model waterfall adalah :

\section{Analisa Kebutuhan Sistem}

Tahapan dalam proses ini merupakan analisa kebutuhan system yang terdiri dari menu menu yang diperlukan dalam pengolahan data penggajian. Berdasarkan hasil analisa, maka peneliti menentukan ada dua kebutuhan dari sistem, yaitu : kebutuhan admin dimana admin dapat mengelola seluruh data yang berhubungan dengan penggajian, selanjutnya adalah kebutuhan dari pimpinan perusahaan dimana pimpinan hanya dapat melihat slipgaji, laporan gaji, melihat laporan absensi dan mengelola data admin.

\section{Desain}

Dalam tahapan ini peneliti merancang desain yang dibutuhkan oleh sistem, menggunakan metode pemodelan berbasis objek yaitu UML yang terdiri dari use case diagram, activity diagram, ERD, LRS, class diagram dan sequence diagram untuk admin dan pimpinan.

\section{Pengkodean}

Dalam penelitian ini peneliti menggunakan text editor yaitu Sublime Text 3, webserver menggunakan program PHP, database yang dipergunakan adalah
MySQL, framework yang dipergunakan adalah CI dan bootstrap, untuk browser yang dipergunakan adalah Google Chrome.

\section{Pengujian}

Balckbox testing di terpkan pada proses ini oleh peneliti dalam penelitian ini.

\section{B. Metode Pengumpulan Data}

\section{Observasi}

Dalam metode ini peneliti melakukan penelitian dengan melihat secara langsung proses penggajian beserta pengolah datanya sehngga menghasilkan hasil akhir yaitu slip gaji untuk karyawan dan laporan penggajian untuk pimpinan.

\section{Wawancara}

Dalam metode ini peneliti melakukan tanya jawab dengan bagian administrasi yang mengelola penggajian di perusahaan.

\section{Kajian Literature}

Dalam melakukan penelitian ini peneliti tidak lepas dari data yang terdapat dari buku-buku yang menjadi referensi seperti artikel ilmiah, jurnal ilmiah dan buku-buku lain yang berhubungan dengan penggajian, metode pengembangan software yang dipergunakan dan literature yang berhubungan dengan aplikasi yanng dipergunakan oleh peneliti.

\section{HASIL DAN PEMBAHASAN}

\section{A. Analisa kebutuhan Sistem}

Analisa kebutuhan sistem yang dianalisis oleh peneliti untuk penggajian, diantaranya adalah :

1. Analisa Kebutuhan Sistem Admin
a. Admin dapat mengelola data karyawan
b. Admin dapat mengelola data jabatan
c. Admin dapat mengelola data pendidikan
d. Admin dapat mengelola data tunjangan
e. Admin dapat mengelola data potongan
f. Admin dapat mengelola data golongan
g. Admin dapat mengelola absensi

2. Analisa Kebutuhan Pimpinan
a. Pimpinan dapat melihat slip gaji
b. Pimpinan dapat melihat laporan gaji
c. Pimpinan dapat melihat laporan absensi
d. Pimpinan dapat mengelola data admin

\section{B. Desain}

Desain yang dipergunakan oleh peneliti adalah metode pemodelan berbasis objek yaitu UML yang terdiri dari use case diagram, activity diagram, ERD, LRS, class diagram dan sequence diagram untuk admin dan pimpinan.

1. Use Case Diagram

Usecase diagram di buat berdasarkan dari hasil analisis kebutuhan dari sistem penggajian. 


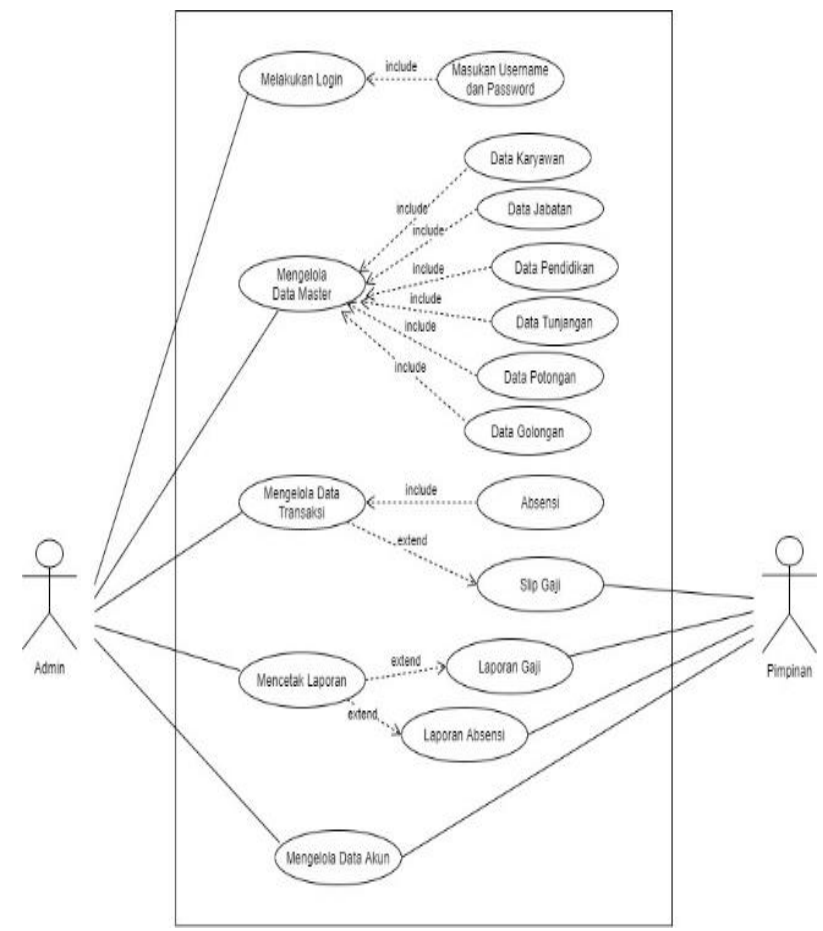

Sumber : Penelitian (2020)

Gambar 1. Use case

\section{Activity Diagram}

Activity diagram di pergunakan untuk menggambarkan proses-proses yang ada didalam proses penggajian di dalam program.

a. Activity Diagram Input Data Karyawan

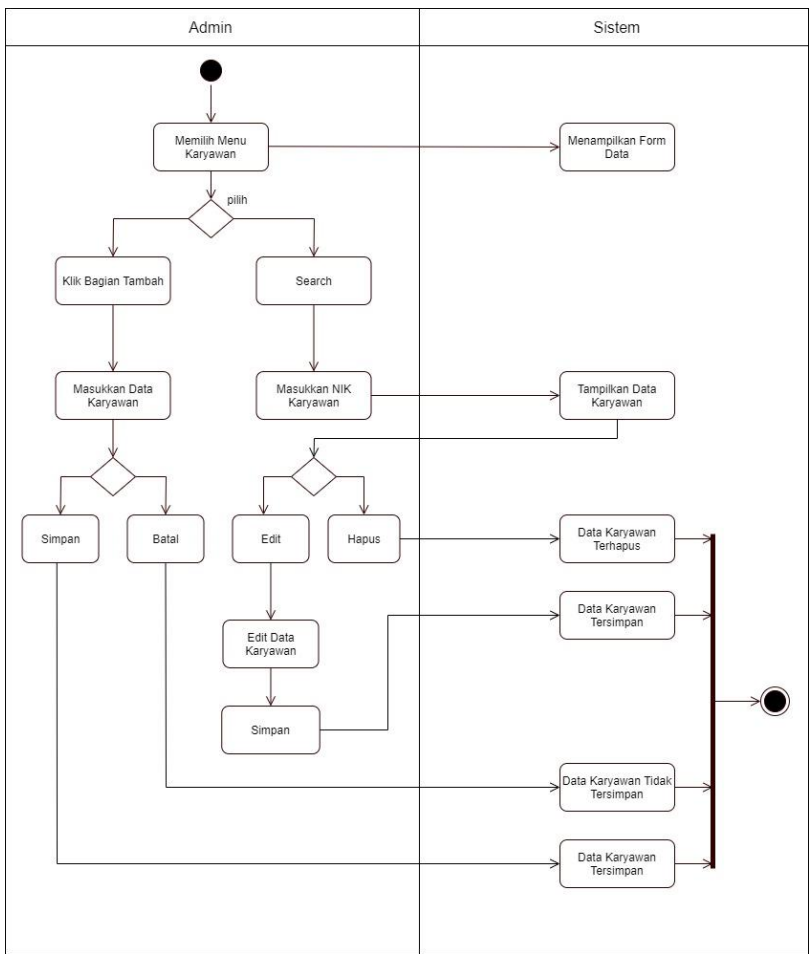

Sumber : Penelitian (2020)

Gambar 2. Activity Diagram Input Data Karyawan b. Activity Diagram Input Data Absensi

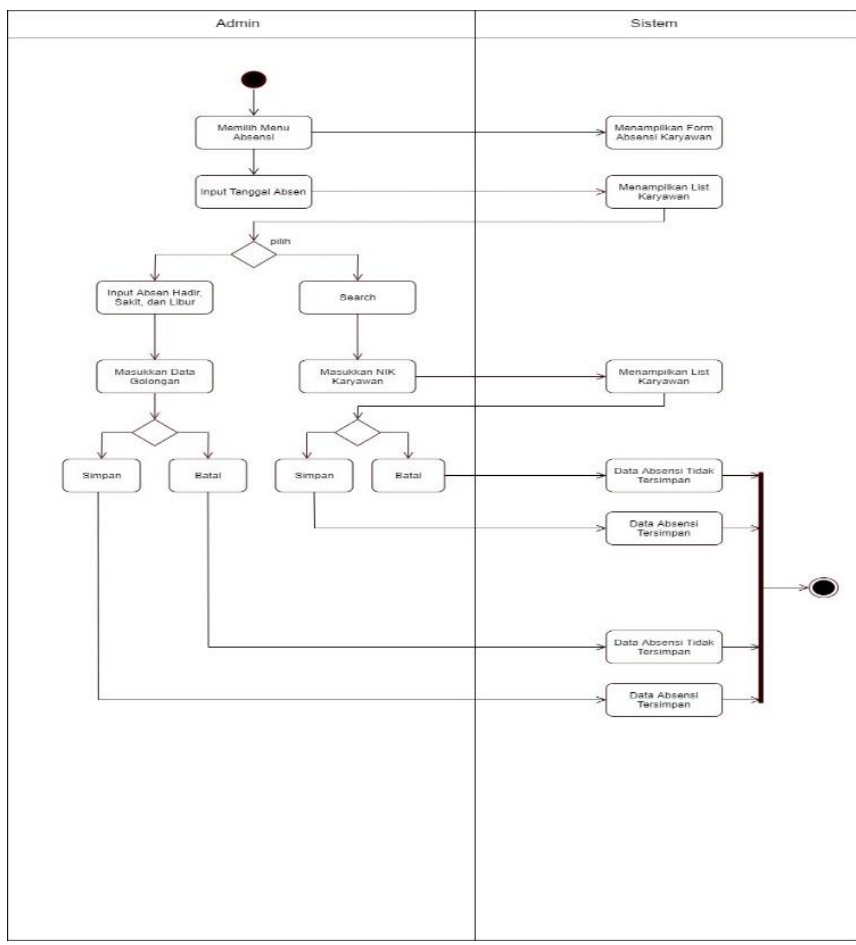

Sumber : Penelitian (2020)

Gambar 3. Activity Diagram Input Data Absensi

c. Activity Diagram Input Data Karyawan

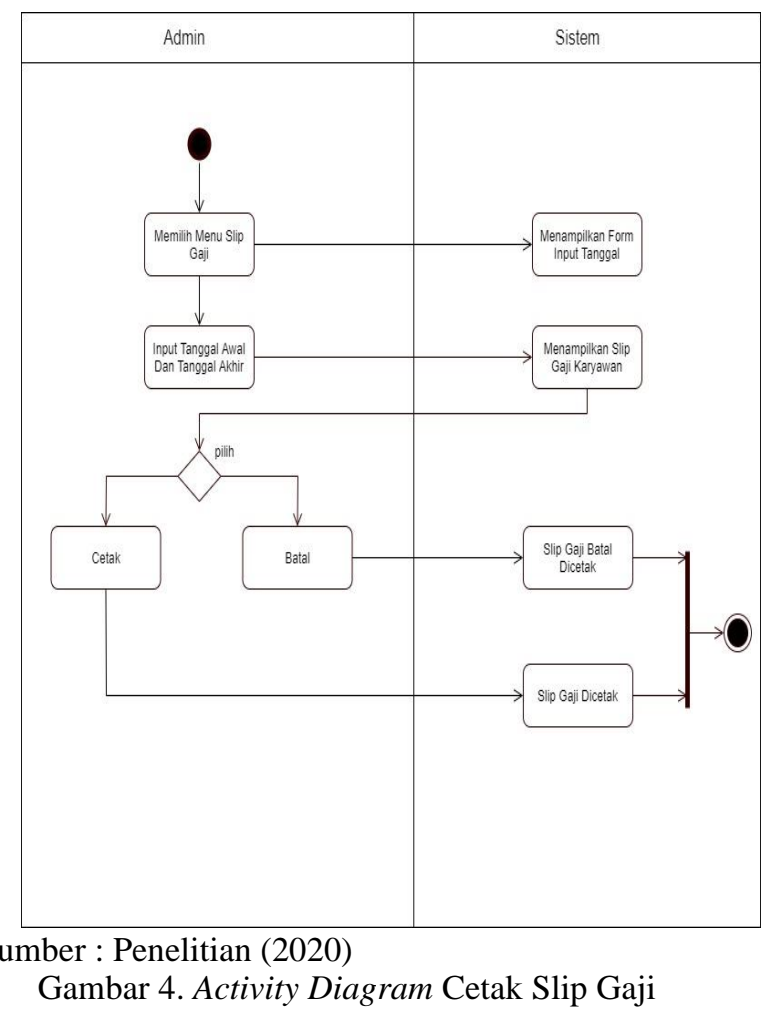


d. ERD (Entity Relationship Diagram)

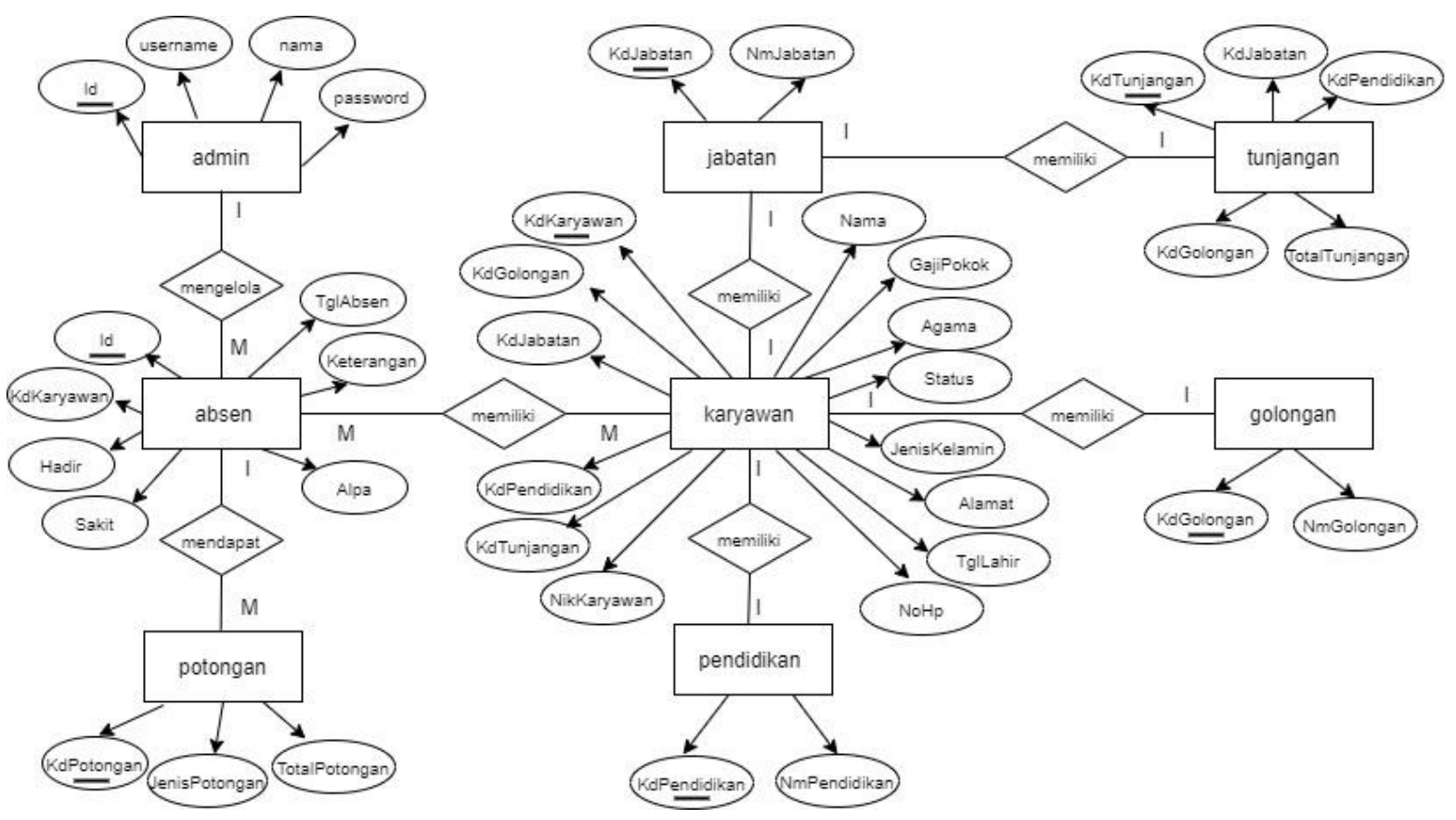

Sumber : Penelitian (2020)

Gambar 5. ERD Aplikasi Mini Payroll

e. LRS (Logical Record Structure
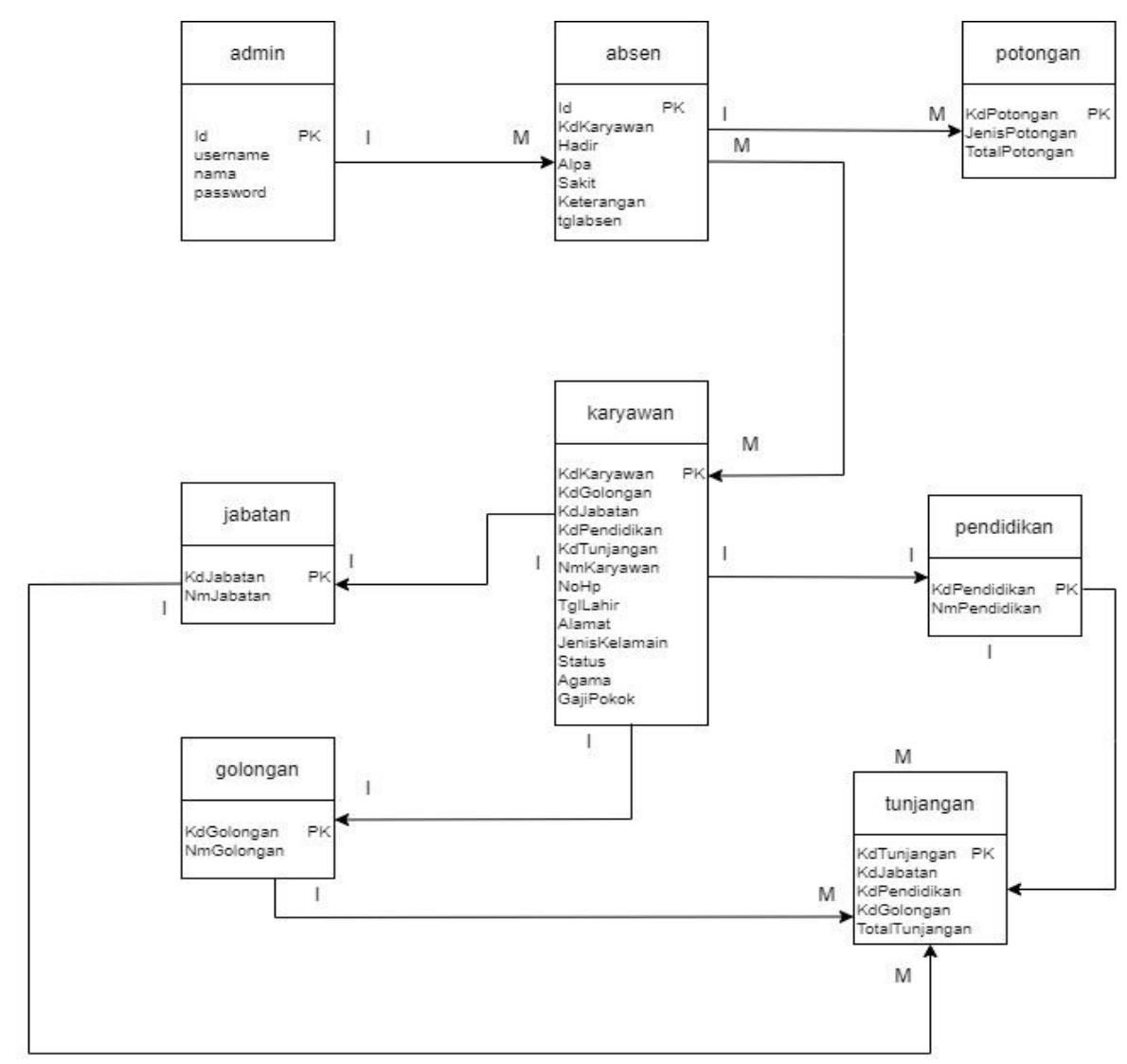

Sumber : Penelitian (2020)

Gambar 6. LRS Aplikasi Mini Payroll 


\section{f. Class Diagram}

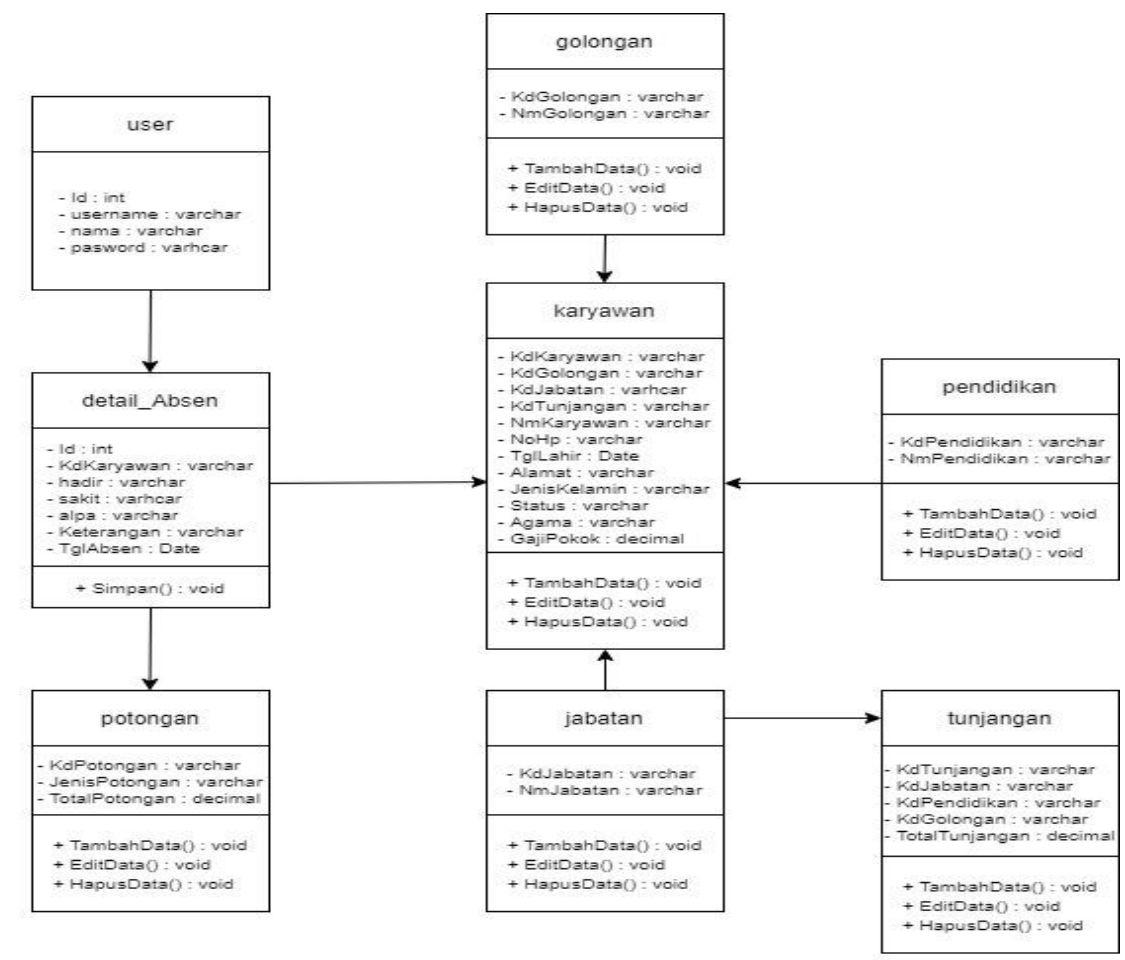

Sumber : Penelitian (2020)

\section{g. Class Diagram}

Gambar 7. Class Diagram

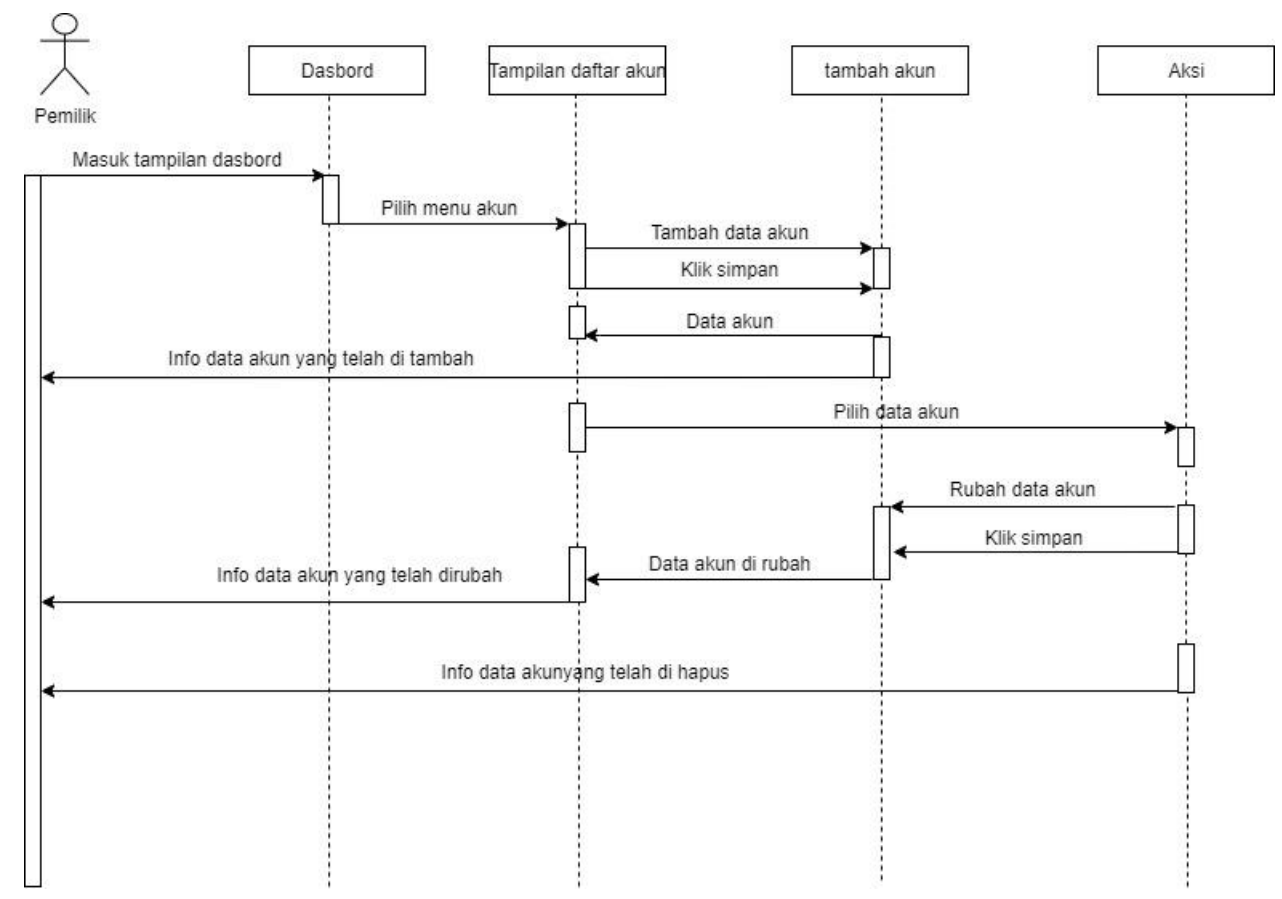

Sumber : Penelitian (2020)

Gambar 8. Sequance Diagram Kelola Data Akun 
3. Tampilan Program Data Karyawan

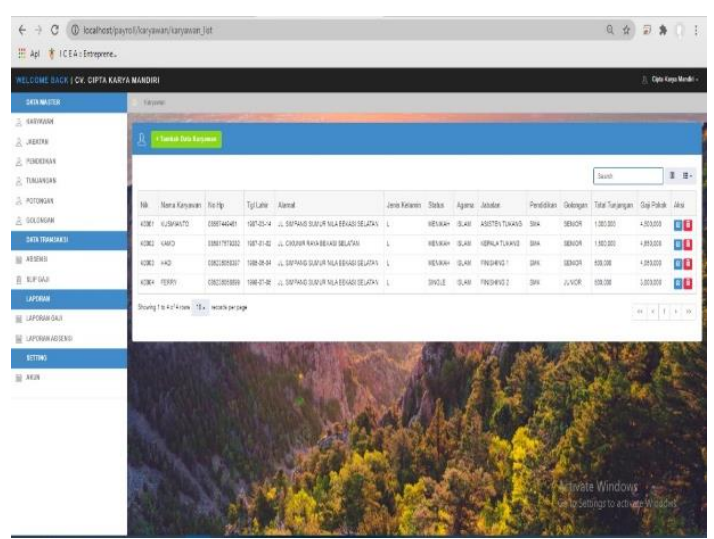

Sumber : Penelitian (2020)

Gambar 7. Tampilan Data Karyawan

4. Tampilan Program Form Absensi

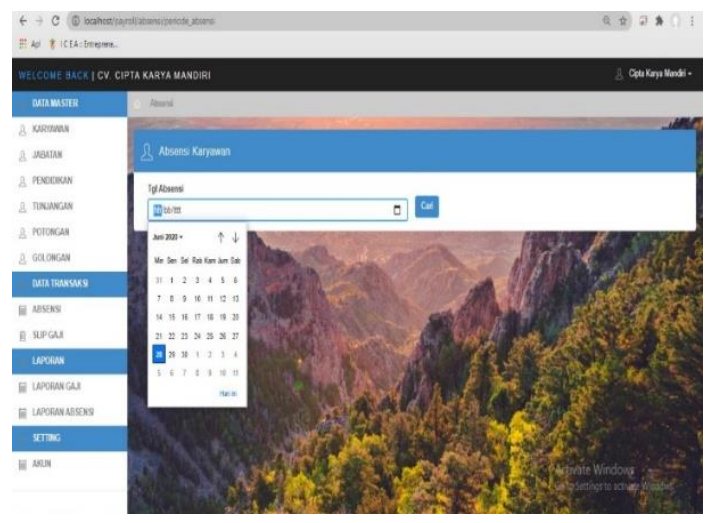

Sumber : Penelitian (2020)

Gambar 8. Tampilan Form Absensi

\section{Pengkodean}

Dalam penelitian ini peneliti menggunakan text editor yaitu Sublime Text 3, webserver menggunakan program PHP, database yang dipergunakan adalah MySQL, frame work yang dipergunakan adalah CI dan bootstrap, untuk browser yang dipergunakan adalah Google Chrome.

\section{Pengujian}

Dalam penelitian ini peneliti melakukan pengujian terhadap form login dan form transaksi absensi untuk melihat apakah validasi yang di berikan untuk formform tersebut sesuai dengan kebutuhan dari sistem.

\section{KESIMPULAN}

Dari hasil penelitian yang sudah dilakukan oleh peneliti, maka dapat disimpulkan yaitu, proses penghitungan gaji yang rumit sudah lebih efisien dan praktis karena sudah otomatis terhitung sistem, pengarsipan data pengeluaran gaji di CV. Cipta Karya Mandiri menjadi lebih rapih dan aman karena data tersimpan di sistem dan kekeliruan antara waktu kerja dengan penghitungan gaji karyawan terminimalisir.

\section{REFERENSI}

Ade Hapsari Lestarin. (2020). Mengelola SDM dalam Dunia Usaha. Www.Medcom.Id. https://www.medcom.id/ekonomi/mikro/akW5 ElBN-mengelola-sdm-dalam-dunia-usaha. Diakses pada tanggal 20 November 2021

Andoko, S. (2013). Pembuatan Sistem Komputerisasi Manajemen Penggajian Pada Comanditer Venoschaf (CV). Mobile Cell Pacitan. Speed Sentra Penelitian Engineering Dan Edukasi, 5(2), 77-82. http://ijns.org/journal/index.php/speed/article/ view/931/918

Entas, S., \& Alawiah, E. T. (2015). Sniptek 2014 Isbn : 978-602-72850-5-7 Perancangan Sistem Usulan Program Penggajian Isbn: 978-60272850-5 -7. 1-4.

Hidayatun, N. (2016). Problem Solving Sistem Penggajian Karyawan Dalam Manajemen Operasional Komputer Menggunakan Pendekatan Sistem. Ijcit, l(2), 1. https://ejournal.bsi.ac.id/ejurnal/index.php/ijcit /article/view/1320

Jurnal, I., Speed, C. S., \& Vol, F. T. I. U. (2012). Nama Field NamaUser HakAkses Password. 9(3), 104-109.

Muhammad, F., Kotjoprayudhi, R. ., \& Yanuar, Y. (2016). Aplikasi Berbasis Web Untuk Pengelolaan Kas Masuk, Kas Keluar dan Laporan Laba Rugi. E-Proceeding of Applied Science, 2(3), 1262-1268. 